\title{
LIMITES CONSTITUCIONAIS NO TRATAMENTO DAS SOCIEDADES LIMITADAS NO NOVO CÓDIGO CIVIL
}

\author{
CONSTITUCIONAL LIMITS IN THE TREATMENT OF LIMITED \\ SOCIETIES IN THE NEW CIVIL CODE
}

\begin{abstract}
Resumo: $\mathrm{O}$ presente trabalho tem como finalidade um estudo sobre o tratamento dado às empresas de pequeno porte e, em especial, as sociedades limitadas. Para tanto, demonstrou-se o desenvolvimento histórico do conceito de empresário e a evolução dos institutos no direito comparado e no ordenamento pátrio concernentes a essas empresas. Possibilitando identificar, atualmente, as lacunas na legislação infraconstitucional, incluindo as inovações do Novo Código Civil, contrariando a ordem econômica constitucional.
\end{abstract}

Palavras-chave: Sociedades limitadas. Empresas de pequeno porte. Leo de quotas.

Abstract: The present work has as purpose a study on the treatment dice to the companies of small load and, especially, the limited societies. For so much, it was demonstrated the historical development of manager's concept and the evolution of the institutes in the compared right and in the brasilian right concerning to those companies. Facilitating to identify, now, the gaps in the legislation ordinary, including the innovations of the New Civil Code, thwarting the constitutional economic order.

Keywords: Limited societies. Companies of small load. Law share.

\section{INTRODUÇÃO}

O advento do Novo Código Civil trouxe para a área jurídica algumas importantes mudanças, especialmente no que tange à inserção, no contexto legal,

"Doutora em Direito Econômico; Professora Convidada do Programa de Mestrado em Direito da UNINCOR, Coordenadora dos LLM's em Direito do IBMEC - RJ; Professora Adjunta da Faculdade de Direito Evandro Lins e Silva - IBMEC; foi Coordenadora dos MBA's em Direito Empresarial e Direito do Consumidor da Fundação Getulio VargasRJ; exerceu as funções de Coordenadora e Professora do Programa de Mestrado em Direito Empresarial da Universidade Candido Mendes-Ipanema; Membro das Comissões de Direito Comercial, de Direito Administrativo e de Direito Comunitário do Instituto dos Advogados do Brasil-IAB e da Comissão de Direito do Consumidor da $\mathrm{OAB} / \mathrm{RJ}$; Procuradora Federal. 
da Teoria da Empresa, uma realidade de fato, mas não de direito, muito embora a jurisprudência já a tivesse agasalhado.

Por outro lado, não houve propriamente definições que pudessem ter significado verdadeiro avanço, como é o caso da ausência de um conceito jurídico para a empresa.

De qualquer modo, grande relevo para o universo societário se deu por intermédio da substituição do comerciante pelo empresário, pois para aquele, com o mero ato de intermediação já se fazia possível vislumbrar seu surgimento, enquanto que para o empresário agrega-se a função de produtor, o que, inexoravelmente, encontra-se mais próximo da realidade do capitalismo industrial vigorante.

Há inúmeros pontos positivos, tais como a inclusão, em regra de caráter geral, da Teoria da Desconsideração da Personalidade Jurídica e do princípio maior da função social, em especial, do contrato, corroboraram para que se possa refletir mais detidamente a importância desse novo código unificado.

Contudo, não se pode olvidar o fato de que, em muitos momentos, especialmente contidos nas espécies societárias, obrou mal o legislador, por um lado, por continuar estipulando regras para modelos empresariais absolutamente em desuso e, por outro, por tentar estabelecer critérios complexos para o ente societário de maior relevo para o contexto econômico nacional e, quiçá, mundial - a sociedade limitada.

É sobre esta modalidade societária que buscamos tratar neste breve estudo, haja vista as imensas controvérsias que irão fazer parte do nosso quotidiano, de agora em diante.

Inarredável a discussão. Alerte-se que não é nossa missão, comprometidos que somos com o universo jurídico, deixar a sociedade civil em estado de perplexidade diante de inovações que, certamente, irão gerar transtornos intransponíveis para a economia.

Crê-se que, talvez, o excesso de zelo tenha sido negativo, pois o legislador ao querer estabelecer regras para evitar efeitos perversos, que desvirtuam o caráter da sociedade limitada, como, por exemplo, a ficção da pluralidade de sócios, na verdade, simulação, para cumprimento de uma norma estabelecida num sistema galgado no liberalismo econômico, fez pesar a mão e findou por presumir a fraude, impondo formalidades exacerbadas.

Infelizmente, ao contrário de ousar manteve-se conservador e olvidou os apelos dos novos tempos, surdo ao clamor do incentivo, meta intentada pelo legislador constitucional, que, fatalmente conduziria à proliferação de núcleos da iniciativa privada, com essa modelagem societária. 
Por todos esses motivos e mais o fato de considerarmos que existem limites de natureza constitucional que não podem, de modo algum, ser desrespeitados, é que nos aventuramos neste debate.

\section{A UNIFICAÇÃO DO DIREITO PRIVADO}

\subsection{Breve Histórico}

O fenômeno da unificação do direito vem expressar a harmonização dos dois pilares do Direito Privado no Brasil quais sejam: o Direito Civil e o Direito Comercial.

Ocorre que tal formatação não é novidade no Direito, tanto isso é verdade que o Código Civil italiano de 1942, passou a disciplinar as matérias civis e comerciais. Tal uniformização, no entanto, já havia surgido em 1881, na Suíça com o Código Federal das Obrigações. Todavia, pontifica o texto italiano exatamente por vir substituir a teoria dos atos de comércio que, inclusive, prevaleceu no texto comercial brasileiro de 1850, muito embora a doutrina e a jurisprudência tenham adotado a Teoria da Empresa como paradigma da atividade econômica.

Importante ressaltar que, a supra-indicada unificação traz consigo algumas questões que merecem reflexão.

Em primeiro lugar, na discussão da autonomia de um ramo do direito em relação ao outro, a questão é: com a reforma, fica o Direito Comercial submetido aos postulados do Direito Civil? Perde sua autonomia, o que equivaleria a dizer que deixa de ser um ramo autônomo do direito.

Para além das bases da dicotomia do direito, que o pressupõe Público ou Privado, uma vez que tal embate já se encontra ultrapassado em suas bases, é de ressaltar que as tentativas de unificação do direito privado no Brasil remontam a outros tempos, contudo, somente agora se dá sua implementação.

Em termos mundiais, a corrente unionista teve em Cesare Vivante seu maior expoente, defendendo tenazmente a unificação do Direito Privado em 1888. Contudo, mais tarde, em 1919, abdicou de seus ideais, cedendo à corrente dicotômica do direito. Nesse sentido, ratificou a diversidade de métodos, de atividade e de área, dos direitos Comercial e Civil, importando na impossibilidade de reunião em um único diploma legal.

Alfredo Rocco, por seu turno, expressamente identifica os motivos que impõem a dicotomia:

as exigências da classe mercantil, setor especial da sociedade, demanda a geração de um ramo distinto que possa atender eficientemente as ingentes 
necessidades para a sobrevivência e desenvolvimento do setor; a necessidade de simplicidade, de celeridade e de informalidade das atividades mercantis; proficiente tutela jurídica do crédito, como elemento fomentador da atividade negocia. (1931 apud MARTINS, 1996, p. 53).

Diversas incursões no direito pátrio ocorreram no sentido da unificação do Direito Privado, especialmente no século XIX, quando Teixeira de Freitas, em 1867, destaca a necessidade de unificação dos códigos Civil e Comercial.

Outras tentativas ocorreram no mesmo sentido. Em 1911, Inglês de Souza recebeu a incumbência de reformar o Código Comercial de 1850. Esse jurista tinha a convicção de que o Direito Comercial havia absorvido o Direito Civil, uma vez que o interesse social se sobrepunha ao individual. Todavia, não alcançou o seu intento, pois, em 1916, Clóvis Bevilacqua consegue promulgar o Código Civil.

Em 1962, mais uma vez, buscou-se a unificação do Direito Privado por intermédio da criação de um Código de Obrigações e outro Civil, pelas mãos de Caio Mário da Silva Pereira e Orozimbo Nonato e, mais uma vez, não logrou sucesso.

Em 1972, uma Comissão formada por juristas de destaque, encabeçada pelo Prof. Miguel Reale, recebeu a incumbência de unificar as legislações Comercial e Civil, no sentido de encampar as novas correntes e tendências do Direito Privado.

Como é sobejamente conhecido, esse projeto, após exaustivas discussões, materializou-se no Novo Código Civil, promulgado por intermédio da Lei 10.406 de 10 de janeiro de 2002, que entrou em vigor em 10 de janeiro de 2003.

\section{O DECRETO 3.708/19}

\subsection{Gênese da sociedade limitada}

O histórico da sociedade por quotas vai além do direito pátrio, pois é importante que se identifique onde esta modalidade societária efetivamente surgiu e qual a finalidade de sua gênese em termos mundiais.

Com efeito, este ente empresarial foi elaborado, originariamente, na Alemanha, em fins do século XIX.

O momento vivido pela Alemanha era de intenso desenvolvimento econômico, havendo uma preocupação do legislador em atender às expectativas do comércio criando um tipo societário capaz de corresponder aos interesses imperantes, no sentido de promover a consecução das finalidades econômicas e, ao mesmo tempo, de caracterizar uma sociedade autônoma a par das já existentes. (MARSHALL, 2002, p. 7). 
Como ensina Raúl Ventura (1993, v. 1, p. 9) ao comentar o Art. 197 do Código das Sociedades Comerciais:

A lei alemã surgiu como deliberada tentativa de fomento econômico por meio de uma instituição jurídica. Procurou-se induzir à criação de novas empresas, tanto na Alemanha européia como nas suas colônias, oferecendo aos interessados um tipo de sociedade intermédio entre a sociedade baseada na responsabilidade ilimitada dos sócios e a sociedade anônima, para se conseguir reunir os pontos atraentes de ambas, sem as correlativas desvantagens.

É evidente a preocupação relativa ao desenvolvimento econômico desde a gênese deste modelo societário.

\subsection{A incompletude e a realidade econômica}

Consta da Exposição de Motivos do projeto de lei das S.A., que adquiriu o n. 1.844, a preocupação de limitar a responsabilidade do empresário, mas, na verdade, após consultas feitas às Câmaras de Comércio, houve uma tendência a reformála. O então deputado Oechelraeuser, defensor da aludida reforma, expôs em memorial a sua apreensão, tendo em vista o momento econômico experimentado:

é preciso que o princípio da responsabilidade limitada que vivamente interessa à vida econômica, penetre nas sociedades de caráter individualista, em que diretamente colaboram o capital e a inteligência: com capital igual e atividade humana igual, as sociedades individuais produzirão, incontestavelmente, valores superiores aos das sociedades coletivas. (1908 apud PEIXOTO, 1956, p. 14).

$\mathrm{Na}$ verdade, a legislação referente às sociedades anônimas não era compatível com as pequenas empresas que então se organizavam, sob a modalidade, em nome coletivo, onde a responsabilidade dos sócios era ilimitada. Daí, a total ausência de alternativas pois, ou se submetiam à organização em nome coletivo e tinham a sua responsabilidade ilimitada, ou se submetiam às imensas e desgastantes formalidades da sociedade anônima.

O Governo mostrou-se preocupado com tal situação, tendo em vista a rápida industrialização no período imediatamente subseqüente à guerra de 1870, uma vez que ambas as modalidades societárias, então existentes, não correspondiam às evidentes necessidades de expansionismo do comércio, daí a busca de alternativas com o intuito de reverter este quadro.

Forças contrárias à inauguração de uma nova modalidade societária, ao lado da sociedade anônima, manifestaram-se, encabeçadas principalmente pelo 
deputado Hammacher, que combatia a criação de outra unidade social, especialmente de cunho individualista. No entanto, setores comerciais exerceram pressão em sentido contrário. Na verdade, em 1888, o Colégio dos antigos comerciantes berlinenses submeteu à apreciação do Governo uma proposição exatamente de cunho individualista e de responsabilidade limitada.

Ao final daquele ano, diversas proposições legislativas foram enviadas ao Governo e culminaram em projeto de lei, convertido na lei promulgada em 20 de abril de 1892, pelo imperador Guilherme II; deu-se, portanto, a gênese da sociedade limitada - Gesetz, betreffend die Gesellschaft mit beschraenkter Haftung - GmbH.

A técnica legislativa empregada pelo legislador alemão demonstra a sua preocupação em abranger as diversas facetas deste novo tipo societário, pois prevê inúmeras hipóteses, minudentemente descritas, como por exemplo: as relações jurídicas entre a sociedade e seus sócios, a constituição da sociedade, formas de representação e exercício da gerência, modificações estatutárias, dissolução e liquidação; tudo em oitenta e dois parágrafos.

O legislador alemão, valendo-se desta técnica, contrariou (de certa forma) o modelo que caracteriza a norma jurídica pela sua generalidade, abstração e impessoalidade, capazes de abranger inúmeras variantes de conduta (MARSHALL, 1995, p. 141).

A utilização de tal técnica legislativa pelos alemães veio na esteira do período da Codificação, que grande influência exerceu na Alemanha exatamente pela tendência de unificação do direito. Não mais convinha à Europa, como um todo, o particularismo feudal que até então imperava. Isso foi possível e necessário, tendo em vista as novas condições relativas à intensificação das relações humanas, em especial comerciais, estimuladas pelo desenvolvimento dos transportes, gerador de maior proximidade entre os povos (LIMA, 1977).

A necessidade de nova modalidade societária, ou seja, diferente das sociedades anônimas, bem mais complexas e de difícil mobilidade comercial, fez-se sentir igualmente na Inglaterra.

Ocorre que na tradição jurídica inglesa, o costume antecede à lei. Isso fez com que, apesar de terem surgido em 1862, as sociedades limited by shares (sociedades anônimas do direito continental) e na prática se constituído as private companies (companhias privadas) somente em 1900, através do Companies Act, reconheceu-se o novo tipo societário, que apenas em 1907 foi regulamentado.

Em realidade, não se pode dizer que o nascimento da sociedade de responsabilidade limitada tenha ocorrido na Inglaterra, pois as private companies não são as sociedades de responsabilidade limitada existentes no direito 
continental. O comercialista João Eunápio Borges (1971) alerta para o fato de que as private companies,

não passam de sociedades anônimas simplificadas e dotadas de características especiais, como a limitação do número de acionistas, restrição ao direito de transmitir as ações, proibição de recurso à subscrição pública, menor rigor legal. São, porém, inconfundíveis com o novo tipo de sociedade que é criação originária da Alemanha. (p. 338).

Desta forma, não se pode dizer que a Inglaterra foi a introdutora, no direito legislativo, desse tipo de sociedade, até porque, para muitos, tratava-se de desdobramento da S.A. Na seqüência, os três primeiros países que a transformaram em lei foram Alemanha (1892), Portugal (1901) e Áustria (1906). No entanto, o fato da sociedade por quotas ter se difundido por outros países a curtíssimo prazo, prova que o problema econômico sofrido pelo comércio da época não se restringia a apenas um ou poucos países, mas constituía um problema econômico dos comerciantes do tipo médio, que precisavam de um novo modelo de sociedade comercial que atendesse às suas expectativas.

Em 1901, Portugal legislou sobre a sociedade "por quotas” de responsabilidade limitada, regulando a previsão da vida administrativa da sociedade, seu registro e dissolução, além da emissão de títulos de obrigações e a fiscalização da sociedade de responsabilidade limitada, tudo isso através de uma descrição detalhada ${ }^{1}$. De forma geral, houve por parte do legislador português uma preocupação significativa em orientar-se segundo a lei alemã. Assim como ocorreu na Alemanha, o meio comercial português também manifestou-se no sentido de buscar uma alternativa para os problemas enfrentados pelos comerciantes médios da época, tais como a dificuldade de constituição de sociedades anônimas e a necessidade de limitação da responsabilidade dos sócios² .

A lei portuguesa de 1901, que se encontrava superada, foi reformulada. Atualmente, a regulamentação da organização empresarial lusitana é a prevista

${ }^{1}$ A antiga lei portuguesa de sociedade por quotas de responsabilidade limitada era composta por sessenta e cinco artigos minudentemente descritos, divididos em 9 (nove capítulos).

${ }^{2} \mathrm{O}$ principal motivo de orientação da lei portuguesa se fazer nos moldes da alemã, devese ao fato de que a "Câmara de Comércio e Indústria de Lisboa em 1896, recomendou a promulgação de uma lei como a alemã, no mesmo sentido se manifestando a Associação Industrial Portuense e uma comissão de destacados vultos do comércio dessa cidade". Cf Parecer da Comissão de Legislação Civil da Câmara dos Deputados ao projeto de lei portuguesa. (SOUTO, 1941, p. 265). 
no Código das Sociedades Comerciais aprovado pelo Decreto-lei 262/86, de 2 de setembro daquele ano, que expressamente revogou a Lei de 11 de abril de 1901 a antiga lei das sociedades por quotas de responsabilidade limitada. A partir dessa data todas as espécies de sociedades passaram a ser tratadas em diploma legal único.

O Código das Sociedades Comerciais português deu nova feição aos tipos societários. Não se trata de uma mera consolidação, ou seja, agregação de textos esparsos, mas verdadeiras inovações com estruturas individualizadas e próprias. O Título III trata das Sociedades por Quotas.

Retornando ao contexto histórico, em pouco tempo deu-se a difusão desta nova forma de sociedade em diversos países além dos supracitados, tais como: França, Liechenstein, Turquia, Cuba, Hungria, Argentina e tantos outros. A introdução desta configuração societária na legislação dos diversos países ocorreu por meio de lei específica ou com a sua inserção no texto do Código Comercial respectivo.

Ressalte-se o fato de que em alguns países, tais como Hungria e Argentina, as regulamentações originais são reprodução idêntica da lei alemã. No entanto, a lei de sociedade de responsabilidade limitada da França, que a introduziu em 1925 em seu ordenamento jurídico, possui peculiaridades que não chegam a descaracterizá-la, pois a sua essência não é alterada, mas que, por uma questão de adequação tende para vertentes diferentes. Seguiram a orientação francesa Liechenstein e Cuba, dentre outros.

\subsection{A Lei de Quotas propriamente dita}

O Brasil foi o quinto país no mundo a adotar este tipo societário, que se consolidou em 10 de janeiro de 1919, através do Decreto 3.708. Bem antes desta data, entretanto, já havia uma grande preocupação dos juristas brasileiros.

O momento político-econômico vivido pelo Brasil, tanto interna como externamente, era de crise. O doutrinador Hermano Villemor do Amaral (1938) faz uma apreciação do quadro da época, dizendo que:

no exterior, concluíra o Império a guerra do Estado Oriental e pacificara essa república da lucta civil, que ha tanto tempo a devastava, e apparelhavase, com as primeiras medidas, para a Gerra do Paraguay, que muito nos havia de custar, como custou. No interior, ainda se fazia sentir os effeitos da tremenda crise financeira, que explodira em todo o Império (p. 45-6).

Em 1865, José Thomaz Nabuco de Araújo, então Ministro da Justiça, elaborou Projeto, que alguns comercialistas dizem ser o precursor da sociedade limitada. 
No entanto, segundo Fran Martins $(1960)^{3}$ há apenas identidade quanto à limitação de responsabilidade dos sócios entre esses dois tipos de sociedade, pois a do Projeto de Nabuco de Araújo, nada mais é do que uma sociedade anônima simplificada. Ou seja, uma sociedade anônima na qual vem a ser desnecessária a autorização do governo para funcionamento, enquanto que a lei das sociedades por quotas de responsabilidade limitada de 1919 criou, efetivamente, um novo tipo de sociedade com características próprias.

O Projeto de Nabuco de Araújo, no entanto, não obteve aprovação do Conselho de Estado, que também fora ouvido 4 . O fundamento principal e que deu origem à sua não aprovação foi expresso no Parecer do Dr. Manoel Ignacio Gonzaga $^{5}$. No Parecer, o ilustre advogado alega que "não se justificava a criação de uma espécie de sociedade anônima livre que era o caso da sociedade limitada" ${ }^{6}$.

A tentativa de introduzir uma nova forma de sociedade não findou aí, pois mais tarde, o deputado gaúcho Joaquim Luís Osório (AMARAL, 1921, p. 59) retomou a questão desta nova modalidade social. Após ser declarada a constitucionalidade e a utilidade do Projeto de Joaquim Luiz Osório, esperava-

${ }^{3}$ Ver também Amaral (1921, p. 47-49), que relatou a manifestação de Waldemar Martins Ferreira: "Houve, todavia, um projeto de as instituir (as sociedades de responsabilidade limitada por quotas). Foi em 1865. Formulou-o Nabuco de Araújo, ministro da Justiça, que ouviu sobre ele vários jurisconsultos e autoridades comerciais. E no mesmo sentido, opinaram Carvalho de Mendonça, Bento de Faria, Oliveira e Silva, Dionísio da Gama, Noredino Silva."

${ }^{4}$ Em virtude do Parecer datado de 9 de junho de 1866, da seção de Justiça constituída por Pimenta Bueno, Viscondes de Uruguay, Jequitinhonha e Itaboray, e Manoel Felizado, foi o projeto rejeitado, conformando-se o imperador D. Pedro II com esse Parecer, pela resolução de 24 de abril de 1987. Ver, também, Amaral (1921, p. 59).

${ }^{5}$ Parecer do Dr. Manoel Ignacio Gonzaga: "Sobre o assumpto, é de ser destacado o brilhante parecer do notavel advogado Dr. Manoel Ignacio Gonzaga. Seu trabalho é longo, minucioso e completo. A grande ilustração e a sabida independencia desse eminente advogado, deram ao seu parecer um cunho próprio, que o constitue uma verdadeira e excellente obra de critica ao projecto.

Entrando em considerações geraes acerca do projecto, mostrava que a nova sociedade tinha grandes pontos de contacto com as sociedades anonymas, que quasi se confudia nestas, si não fôra dellas separar-se por não carecer de approvação do poder publico antes de começar a funccionar. Essa autorisação, não sendo um elemento intrinseco à constituição dessas sociedades, mas, apenas uma formula, extranha a ellas, dictada pelas necessidades publicas e ordem na administração, não é um traço differenciador 
se que o mesmo fosse emendado ${ }^{7}$. No entanto, foi aprovado sem discussões ou emendas tanto na Câmara dos Deputados como no Senado Federal (MARTINS, 1960, p. 65), tornando-se o Decreto 3.708.

Para Hermano Villemor do Amaral (1921):

foi pena que esse Decreto, cuja proposta passou em branca nuvem pelas Casas do Congresso, não se houvesse limitado às disposições do Projeto de Inglês de Souza, remetendo-as, determinadamente, às que lhes são aplicáveis, tanto do Código Comercial, como do Decreto 434 e das leis que a este substituíram em muitos dos seus dispositivos, como fácil seria por indicação de outros capítulos do próprio Projeto, que entendem com a matéria das sociedades limitadas, e fosse buscar, na lei portuguesa de 1901, outros elementos que só lhe prejudicaram a contextura [...] ocasionando, por deficiência e inovações, o desacerto com que tem sido interpretada a criação das novas sociedades, e privando-nos de possuir a obra do extinto comercialista, correta e duradoura, a qual tem irradiações de um cérebro verdadeiramente luminoso (p. 65).

entre ellas e as sociedades novas, que eram verdadeiras sociedades livres, por opposição às anonymas, que dependiam de approvação do poder.

Nessa conformidade, achava que não se devia crear um typo novo de sociedade, mas modificar o typo existente, e textualmente, assim se exprimiu: - 'alterar a parte do Codigo, relativo às sociedades anonymas, seria melhor do que fazer-se uma nova lei, fóra do Codigo, e crear uma nova especie de classe com alteração dos princípios de direito, porque, na sciencia, a sociedade livre não é classe de especie distincta da sociedade anonyma' [....].

Pareceres de Caetano Furquim de Almeida e Bartlett James [..] declarava que ninguém podia, então, discutir que a lei ingleza de 1862 e a lei franceza de 1863, tinham sido fontes de riqueza e de desenvolvimento da industria e da agricultura." (AMARAL, 1921, p. 56-58), em nota de rodapé.

${ }^{6}$ Tomando por base parte do projeto do novo Código Comercial de autoria de Inglês de Souza, datado de 1912 - que inseria a questão da sociedade limitada em capítulo compreendido entre os Artigos 72 a 83 - apresentou à Câmara dos Deputados então em 20 de setembro de 1918 o Projeto que deu vida à sociedade por quotas de responsabilidade limitada.

${ }^{7}$ Segundo Fran Martins (1960, p. 269): "o aproveitamento (do antigo projeto de Código Comercial de Inglês de Souza, bem como das leis portuguesa e alemã) se fez apressadamente, sem os necessários estudos que deveriam tê-las escoimado das suas imperfeições, resultando daí possuirmos uma lei que é um suplício para os intérpretes, com deficiências inconcebíveis em face da sua importância." 
Os doutrinadores que comentam a aprovação imediata da lei de sociedade por quotas brasileira não mencionam expressamente quais os motivos da ausência de emendas e discussões em ambas as Casas do Congresso Nacional. Todavia, perpassa a seguinte situação: havia grande ansiedade dos segmentos comerciais e industriais nacionais em ver aprovada uma lei nos moldes das tão bem sucedidas alemã, portuguesa, austríaca e inglesa. Acresça-se a isso a tramitação anterior no Congresso por 6 anos - foi apresentado em 1912 - do Código Comercial de Inglês de Souza, sem, contudo a obtenção de sua aprovação. Desta forma, fica clara a pressão sofrida pelo Congresso e que resultou na aparente indiferença para com o Projeto de lei do Deputado Joaquim Luiz Osório.

Como se observa da análise supra feita por Hermano Villemor do Amaral, a nossa lei das sociedades por quotas de responsabilidade limitada tem como antecedente histórico a lei portuguesa de 1901. Há, inclusive, dispositivos na lei nacional que são ipsis literis os da lei portuguesa. Desta forma, impossível analisar o conseqüente sem fazer referências ao antecedente.

A lei portuguesa primitiva, por sua vez, fundamentou-se na alemã, que foi a precursora. No entanto, a lei brasileira de quotas não se identifica por completo com as precedentes.

A técnica legislativa empregada no caso do texto legal brasileiro foi a da concisão. O legislador pátrio achou por bem expurgar o excesso de minúcias da lei portuguesa, quando da elaboração da lei nacional. Desta forma, o deputado Joaquim Luiz Osório condensou o capítulo do Projeto do Novo Código Comercial de Inglês de Souza que se refere à sociedade de responsabilidade limitada, como já descrito acima, acrescendo artigos inteiros da lei portuguesa.

No caso brasileiro, nosso legislador ordinário não tem se mostrado interessado em encontrar uma linha diretriz que venha efetivamente a atender à necessidade de adequação a uma realidade emergente, apesar dos conflitos surgidos entre os sócios-quotistas levados aos tribunais, sem falar naqueles que não chegaram ao Judiciário ou aqueles que ainda estão se desenrolando em primeira instância; sem falar, também, na questão relativa ao incentivo que é previsto na Constituição Econômica da Carta Constitucional vigente, que identifica, como meta de desenvolvimento, o incentivo à pequena empresa.

$\mathrm{Na}$ verdade, a sociedade por quotas de responsabilidade limitada se presta a qualquer dimensão empresarial, ou seja, à micro, pequena, média e grande empresa, muito embora tenha se convencionado que a grande empresa e, em alguns casos, a média, se beneficiam mais de uma outra modalidade, que seria a sociedade por ações.

Alerte-se, todavia, para o fato de que, com o advento do Novo Código Civil, 
pode haver uma reviravolta nesta situação, pois as sociedades de pequeno porte, na atual sistemática, não terão antigos benefícios de simplificação de sua rotina empresarial.

\section{AS EMPRESAS DE PORTE REDUZIDO E A SIMPLICIDADE DAS SOCIEDADES DE RESPONSABILIDADE LIMITADA}

\subsection{O fomento determinado constitucionalmente}

Numa economia de mercado, inserida num contexto de cunho capitalista, o desenvolvimento econômico é a meta e para que a mesma seja atingida, é imprescindível a implementação de alternativas de fomento pelo Estado, entendendo-se fomento como forma de incentivo estatal às atividades da iniciativa privada, que visam o desenvolvimento do país.

A intervenção do Estado no domínio econômico vem sendo a tônica das civilizações, a partir dos diversos regimes adotados pelos governos. Na verdade, a atuação do Estado é fator determinante nas políticas públicas implementadas, uma vez que dele partirá o modelo que deverá reger as relações econômicas na sociedade.

No caso brasileiro, o texto que consolida e legitima a ação do Estado intervindo na economia, consiste na Carta constitucional. O texto constitucional vigente prevê a intervenção do Estado no domínio econômico nacional por intermédio do planejamento, do fomento e do poder de polícia.

A Constituição Econômica, de uma forma geral, é indispensável para o entendimento do processo interventivo estatal. Com efeito, ressalta-se no Brasil o fato de que há limites impostos ao poder do Estado, tendo o mesmo que se manter dentro do universo a ele determinado, observando-se, portanto, o seu campo de atuação, previsto no Art. 170 e seguintes da atual Carta constitucional.

A questão econômica sempre esteve intimamente ligada à questão jurídicopolítica. Evidentemente, não há como cindir-se o ramo do direito denominado constitucional do inegável elo de união com os aspectos econômicos que estiveram presentes ao longo da história.

A Constituição de 1934 foi, verdadeiramente, a primeira Carta brasileira a tratar de questões econômicas, após a vitória da Revolução de 1930. Todavia, no período que vai de 1930 até 1934, durante o Governo Provisório, o mesmo instituiu uma "Constituição Provisória", no dizer de Afonso Arinos (1960), que vigorou até a promulgação do texto constitucional de 1934. 
$\mathrm{Na}$ verdade, tratava-se de reestruturação total daquilo que até então se abordava em uma constituição. No Título IV havia a previsão "Da Ordem Econômica e Social”, que contava com um universo de trinta e um artigos. Nestes artigos pode-se constatar a "consagração da justiça e das necessidades da vida nacional, de modo que possibilitem a todos existência digna e que funcionem como limites à garantia da liberdade econômica" (SOUZA, 1994).

A existência digna está intimamente ligada à questão da satisfação do homem e de sua valoração diante da sociedade, como indivíduo que contribui para o progresso e desenvolvimento da nação, por intermédio de seu trabalho.

A leitura que se pode fazer deste texto constitucional é de nacionalismo, onde há a admissão do monopólio estatal, mas somente em determinada atividade econômica; nacionalização dos bancos de depósito e das empresas de seguros; incentivos à economia popular; reconhecimento dos sindicatos; previsão de proteção ao trabalhador e princípios a serem traçados na legislação trabalhista, bem como a instituição da Justiça do Trabalho, dentre as múltiplas outras disposições de conteúdo econômico.

Ressalte-se o fato de que há historiadores, como Thomas Skidmore (1976, p. 39) que consideram que a "Constituição de 1934 era um produto híbrido"; isto se devia à inserção, no mesmo documento, da ideologia liberal política e do chamado "reformismo econômico".

Somente em 1988, com o advento da Carta política vigente, que seguiu o modelo da carta de Weimar de 1919, deu-se continuidade àquela tipologia de estrutura.

A Constituição da República Federativa do Brasil de 1988 inovou por vários motivos: primeiramente distinguindo a Ordem Social e a Ordem Econômica e, em segundo lugar, incluindo a Ordem Financeira à Ordem Econômica.

Tais inovações serviram para demonstrar a racionalidade da expressão contida nos textos de modo sistemático, muito embora, conforme identifica Eros Grau (1997, p. 41) a ordem jurídica, como sistema que congrega princípios e regras de natureza jurídica "compreenderia uma ordem pública, uma ordem privada, uma ordem econômica, uma ordem social”. Desta forma, ambas, ordem econômica e ordem social, estão contidas numa ordem maior que consiste na ordem jurídica, apesar das imensas controvérsias que cercam a expressão "ordem" ${ }^{8}$.

${ }^{8}$ Entendendo-se, para efeito da presente tese, que se trata da prescrição ou o sistema de regras, ou ainda, a soma de princípios criados para estabelecer o modo pelo qual se deve proceder dentro da sociedade em que se vive, e das instituições de que se participe. $\mathrm{O}$ que equivale a dizer que se trata do conjunto de regras que determinam e regem as atividades dos homens. 
$\mathrm{Na}$ verdade, há maiores críticas quando se agrega a Ordem Econômica à Ordem Social, dentro de um contexto constitucional de sistema democrata. A utilização das duas ordens, expressa na Constituição de 1988, reflete de modo bastante nítido a afetação ideológica da expressão. O que se extrai da leitura dos textos constitucionais, despida de senso crítico, é a indicação de que o capitalismo se transforma na medida em que assume novo caráter social ${ }^{9}$.

Com efeito, a identificação do regime capitalista na Carta constitucional vigente, a partir de seus postulados, aponta para uma transformação destes últimos, no sentido de um alinhamento com o cunho social expresso, não sem antes demonstrar a ausência de espírito crítico indispensável a uma leitura mais apurada do contexto geral. Na verdade, fornecer ao capitalismo uma feição social é, no mínimo, um esforço intelectivo. Talvez se possa ultrapassar tal impasse, por meio de uma leitura de Bem-estar, inegavelmente contida na Constituição vigente, mas não de uma interpretação de capitalismo puro.

\subsection{O desenvolvimento econômico brasileiro incentivando as sociedades limitadas}

A par das outras modalidades de entes societários existentes, muitas delas, somente no papel, as sociedades limitadas tiveram o seu destaque, em especial por se tratar de distinção de patrimônios entre as pessoas física e jurídica, daí a assunção da expressão limitada.

$\mathrm{Na}$ verdade, compartilham desta mesma natureza jurídica a sociedade por quotas e a sociedade por ações. Contudo, como acima se indicou, a modalidade mais utilizada consiste na sociedade por quotas e é exatamente em função das necessidades de expansão deste universo, de certo modo, vocacionado ao pequeno porte se constata a preocupação do constituinte quanto à determinação de seu incentivo.

Ressalte-se o destaque a ser conferido à expressão livre iniciativa que, muito embora tenha sido inserida no caput do supracitado artigo, não se reduz à iniciativa econômica. O Art. $1^{1}$, IV, da Carta Magna também a identifica, mas desta vez como fundamento, e não princípio, ao lado dos valores sociais do trabalho. Todavia, tem-se por certo que a livre iniciativa apontada pelo Art. 170, está intimamente ligada à liberdade de empresa, abrangendo todos os modos de produção, ou como expressa Eros Grau (1997, p. 224): "uma das faces da livre iniciativa se expõe, ninguém o contesta, como liberdade econômica, ou liberdade

${ }^{9}$ Para maior aprofundamento da questão ver Grau (1997, p. 46-52). 
de iniciativa econômica, cujo titular é a empresa.” Neste sentido, a empresa, entendida como atividade econômica com fins lucrativos, está associada à valorização do trabalho livre, que é concebido numa sociedade onde primam a liberdade e o pluralismo.

Os princípios da ordem econômica, traçados nos incisos do Art. 170 consistem na:

1. soberania nacional;

2. propriedade privada;

3. função social da propriedade;

4. livre concorrência;

5. defesa do consumidor;

6. defesa do meio ambiente;

7. redução das desigualdades regionais e sociais;

8. busca do pleno emprego;

9. tratamento favorecido para as empresas de pequeno porte constituídas sob as leis brasileiras e que tenham sua sede e administração no país.

Este último princípio, contido no inciso IX do artigo 170 da Carta política, foi alterado em virtude da emenda constitucional n $\mathrm{n}^{\mathbf{a}} 6$ de 14 de agosto de 1995, sem contudo, perder sua expressão maior que consiste no tratamento favorecido às empresas de pequeno porte.

Tal princípio encontra-se intimamente ligado ao do pleno emprego, quanto à necessidade de fomento às empresas de pequeno porte, pois o que se pretende é a criação de novos postos de trabalho, contribuindo para o crescimento econômico. Daí ser imprescindível a geração de alternativas, que conduzam à expansão do mercado.

Cumpre-se afirmar que não se está falando em favorecimento desmedido de um determinado setor em detrimento dos demais, nem políticas diferenciadas que gerem desequilíbrio no mercado, mas da criação de um ambiente propício aos investimentos privados, que possam constituir um novo pólo de projeção para o desenvolvimento econômico e social brasileiro e geração de emprego.

Neste aspecto desempenha o Estado um papel marcante e definitivo. É ele que, após ouvir os setores produtivos da economia, irá assegurar, de forma eficiente, novos instrumentos de modernização empresarial, fortalecendo a capacidade competitiva do setor privado e eliminando as condições de desigualdade.

Vale ressaltar que com a abertura dos mercados, os produtos tendem a baratear, pois as indústrias, a cada momento, adotam novas técnicas de produção, com a finalidade de baixar custos e posicionar seus produtos no mercado a preços competitivos. Desta forma, percebe-se a indispensabilidade de abrir um leque 
profissional para o empregado, qualificando-o de acordo com as exigências estabelecidas pelos padrões mundiais, mostrando-lhe novos horizontes e criando possibilidades para que o mesmo invista não unicamente como empregado, mas, também, oferecendo-lhe a oportunidade de atuar como pequeno empresário.

No atual quadro vivido pelo país, observa-se o redirecionamento das funções e porque não dizer, do papel do Estado. Num passado recente, principalmente da década de 60 ao fim dos anos 80, a liderança do Estado foi definitiva na condução do processo de crescimento econômico, muito embora esta mesma condução tenha se mostrado ineficiente.

O inchaço desproporcional do Estado nacional e a má condução das perspectivas de crescimento, envolvendo-o diretamente neste processo, já não faziam parte das perspectivas dos anos 90 , muito ao contrário. O que se pretende é que ele funcione bem, enxuto e mais ágil; suas tarefas básicas deverão ser a regulação e a fiscalização das políticas implementadas para o setor privado.

A necessidade de revisão do papel do Estado não se deu exclusivamente no Brasil; trata-se de um apelo global, tendo em vista as tendências internacionais do comércio mundial, e que, evidentemente, teve como moto condutor a competitividade da economia de mercado.

A mundialização do mercado vem gerando para o setor privado retração e diminuição do nível de emprego, o que demonstra que o Estado deverá elaborar políticas que reorganizem o mercado de trabalho, criando novas condições de ocupação da mão-de-obra.

O panorama rural, que já vinha sofrendo com a redução na ocupação da mão-de-obra, fez-se sentir, recentemente, nos setores urbanos da indústria. Este quadro foi descrito pelo IPEA (1998, p. 17) como sendo "uma crise de desemprego não-solucionável pelos instrumentos tradicionais de estímulo à atividade econômica” e, portanto, considerado fator de inquietação.

A solução, ou possíveis soluções, no atendimento desta demanda, recomenda mudanças nas diversas legislações, inclusive nas trabalhistas, que estão intimamente ligadas ao estímulo à iniciativa privada. A diminuição dos encargos que oneram a contratação e a dispensa de empregados e os altos tributos, que aumentam o custo do emprego são, sabidamente, fatores que levam à burla do cumprimento das regras legais. Dentro desta perspectiva, ninguém tem nada a ganhar, pois, perde o empregado, que deixa de ter assegurados seus direitos sociais, e perde o Estado, por deixar de arrecadar, mesmo que em baixos patamares, e por descumprir o pactuado; por fim, perde a sociedade por não haver retorno da poupança interna, via novos investimentos sociais.

Com efeito, a existência de setores informais na economia é menos nefasta 
do que sua total inexistência; mas, é importante ressaltar que podem ser quantificados positivamente, num momento em que a busca do desenvolvimento sustentado da economia é fundamental para todos os países do globo. Os novos segmentos informais do mercado de trabalho vêm "caracterizando-se, não só pela persistência histórica e a ampliação das velhas oportunidades de ocupação informal de baixa produtividade, mas também pelo surgimento de atividades informais de elevada produtividade e alto rendimento" (IPEA, 1998, p. 29). Tal afirmação, deve, ou, pelo menos, deveria, despertar o interesse do setor público em transformar empresas informais em formais.

Inarredável o fato de que somente por intermédio do fomento à livre iniciativa é que poderão ser minorados os efeitos do desemprego crônico e se alcançará o nível razoável de crescimento. Desta forma, é de fundamental interesse de todos os setores econômicos da sociedade brasileira que se vejam cumpridos os dispositivos constitucionais ínsitos em nosso texto econômico que primam pela ampliação das condições que beneficiam a liberdade de empresa.

É de destacar-se que, qualquer legislação que desconsidere os ideais ditados pelo constituinte, falece de condições de se perpetuar.

\section{AS POLÊMICAS TRAZIDAS À BAILA PELO NOVO CÓDIGO CIVIL QUANTO ÀS SOCIEDADES LIMITADAS}

\subsection{Aplicabilidade ou não da Lei de Quotas?}

O estabelecimento da Teoria da Empresa preconizado no Novo Código Civil, a princípio pode parecer um grande avanço em relação aos famigerados atos de comércio do Código Comercial de 1850, malgrado a doutrina não considerar estes e privilegiar a realidade daqueles.

Inolvidável a imperiosidade de atualização de dogmas constituídos sob o regime liberal que, por força de interpretação jurisprudencial, mantinham-se em sintonia ou o mais próximo possível da realidade emergente.

$\mathrm{O}$ advento do NCC tem gerado polêmicas infinitas no campo do Direito Privado. Contudo, ressalte-se que a atividade econômica nacional pode estar a um passo do constrangimento de se ver irremediavelmente alterada.

A transformação das antigas sociedades civis que, para alguns, foram sepultadas pelo surgimento das sociedades simples não gerou tanta controvérsia, quanto a assunção de modelos ultrapassados e em desuso como é o caso das modalidades de sociedades empresárias, tais como: em nome coletivo, em comandita simples, sem mencionar as sociedades em comandita por ações, agasalhadas pelo Novo Código Civil e que são tratadas na Lei das Sociedades Anônima.

Obviamente, que as outras duas modalidades de sociedades empresárias 
integradas ao Novo Código Civil já eram as mais utilizadas em nosso mercado, a saber: sociedades anônimas e sociedades por quotas.

Com efeito, é de destacar o fato de que ao mencionar as sociedades anônimas o legislador reportou-se ao estabelecido na Lei 6.404/76, que é e continua sendo o diploma legal vigorante. Esmiuçando a sociedade limitada, antiga, por quotas, o legislador a restringiu, talvez, na tentativa de sanar algumas questões que, ao longo do tempo, ficaram inebriadas, mas que a jurisprudência já havia se encarregado de harmonizar.

$\mathrm{Na}$ verdade ao tentar nortear questões já pacificadas em nossos Tribunais, obrou mal o legislador, pois restou gerando complexidade onde antes a operacionalidade se fazia de modo simples, o que, invariavelmente incentivara sua proliferação.

Ora o que têm em comum essas duas espécies societárias? Não restam dúvidas que as mais utilizadas modalidades de sociedades no contexto mundial são as sociedades limitadas, tanto sob o manto da por quotas, quanto por ações.

$\mathrm{Na}$ verdade o elemento que mais as torna atraentes é o fato da limitação da responsabilidade de seus sócios/acionistas/quotistas ao capital social ou ao valor da ação.

A manutenção de outras espécies cuja responsabilidade se faz ilimitada e solidariamente de seus sócios, face às obrigações sociais, é inexoravelmente desnecessária.

A opção pela técnica legislativa de esmiuçar a vida das sociedades não nos parece a mais apropriada, exatamente pelo fato de tornar mais agreste a sua constituição.

Sabemos que numa economia de mercado a livre iniciativa desempenha papel inarredável no desenvolvimento econômico das nações. Portanto, qualquer estipulação legal que não conduza à ampliação das bases de fomento de agentes econômicos está fadada a gerar lesões que poderão ser irreparáveis para a sociedade.

No entendimento do professor Sergio Campinho, em sua obra "O Direito de Empresa - à luz do Novo Código Civil” (2003, p. 129):

Como conceito, a limitação da responsabilidade, ao contrário do que muitos afoitamente possam vir a pensar, é fonte propulsora de desenvolvimento econômico e social, na medida em que propicia o exercício mais seguro da empresa e fomenta, via de conseqüência, a sua proliferação, gerando empregos, tributos e a produção de bens e serviços para a comunidade.

Claro está que se percebe uma simbiose entre a sociedade limitada e as empresas de porte reduzido, daí o incentivo às primeiras, constitucionalmente previstas. 
Neste diapasão, a obrigatoriedade de deliberação por intermédio de Assembléia, quando a sociedade for constituída por mais de 10 (dez) sócios (Art. 1.072, § $1^{\circ}$ ) é, no mínimo, um contra-senso. Tal obrigatoriedade terá o condão de onerar imensamente a atividade comercial, na medida em que deverá ser formalizada a sua convocação.

Obviamente, percebe-se que a opção do legislador do NCC jungiu-se apenas ao quantitativo de sócios. O critério de aferição de que uma sociedade por quotas de responsabilidade limitada é de porte reduzido não pode considerar tão somente o número de sócios/quotistas, até porque o Estatuto da Microempresa possui outras bases e condições para o seu enquadramento ${ }^{10}$. Deste modo, o NCC instituiu condições de órbita geral em sede especial, determinada pelo Poder Originário.

Falece ao Poder Ordinário competência legislativa para criar condições não agasalhadas pelo constituinte. Daí, a total impossibilidade de considerar conformes os dispositivos contidos no NCC, que estipulam complexidade de tratamento às sociedades limitadas, na verdade, as antigas sociedades por quotas de responsabilidade limitada, do recém-enterrado decreto 3.708/19.

O Art. 1.078, por sua vez, estabelece a freqüência das Assembléias de Sócios. A instituição da obrigatoriedade do Livro de Atas é outra formalidade que dificulta a vida da sociedade. Tais burocracias são verdadeiros entraves à vida das empresas de porte reduzido, se não vejamos, houve utilização do paradigma da Lei das $S$. A, no que tange à Assembléia de sócios e, obviamente, quanto a sua convocação e posterior registro das atas em órgão competente. Para uma empresa de médio e grande porte, tais exigências se constituem em meras formalidades de sua existência, pois se pressupõe número considerável de empregados para o desempenho e observância de tais exigências legais, bem como fundos que lhe dêem provimento ${ }^{11}$.

${ }^{10}$ Lei 9.841/99 - Estatuto da Microempresa e da Empresa de Pequeno Porte: Art. $2^{\underline{a}}$ Para os efeitos desta Lei, ressalvado o disposto no art. $3^{\underline{a}}$, considera-se: I - microempresa, a pessoa jurídica e a firma mercantil individual que tiver receita bruta anual igual ou inferior a $\mathrm{R} \$ 244.000,00$ (duzentos e quarenta e quatro mil reais).

II - empresa de pequeno porte, a pessoa jurídica e a firma mercantil individual que, não enquadrada como microempresa, tiver receita bruta anual superior a $\mathrm{R} \$ 244.000,00$ (duzentos e quarenta e quatro mil reais) e igual ou inferior a $\mathrm{R} \$ 1.200 .000,00$ (hum milhão e duzentos mil reais).

${ }^{11}$ Ver mais profundamente em Sérgio Campinho (2003., p. 147-248). 
A imensa maioria de agentes econômicos no Brasil, cerca de 97\% das empresas, se constitui em Sociedades por Quotas, em face de inúmeras vantagens que as mesmas apresentaram ao longo dos anos, dentre elas:

Ausência de autorização para constituição;

Informalidade de procedimentos do dia-a-dia da empresa;

Maior agilidade na tomada de decisões, dado a proximidade de seus sócios;

Simplicidade do contrato social

O professor Áttila de Souza Leão Andrade Júnior, em sua obra "Comentários ao Novo Código Civil - Direito das Sociedades”, especificamente no que tange à comparação entre as sociedades por quotas e as sociedades por ações, expressamente indica:

A facilidade operacional e administrativa, ao contrário, por exemplo, das sociedades por ações, a sociedade por quotas de responsabilidade limitada pode ser administrada por um único gerente, que aliás, nem sequer necessita ser sócio. Isto acelera o processo decisório dessas sociedades relativamente ao dia-a-dia da sociedade [...]. (ANDRADE JÚNIOR, 2002, p. 181).

Uma das poucas desvantagens da Sociedade por Quotas em relação à S. A consistia na obtenção de recursos para investimento, pois no primeiro caso teria que fazê-lo buscando em instituições financeiras e, por conseguinte, arcando com o ônus do financiamento, que inclui juros, serviços bancários, correção etc. enquanto que no segundo caso a emissão de ações concretizava a obtenção de ditos recursos.

Tratou o legislador do NCC de inserir no contexto da Sociedade Limitada a vida desta tão difundida espécie societária, não mencionando em momento algum a lei especial que lhe deu origem, ou seja, o Decreto 3.708/19.

Inarredável o fato de que os dezenove artigos que compõem a Lei de Quotas, em diversos momentos carecem da estipulação do Código Comercial de 1850, quanto à sua constituição e supletivamente a Lei 6.404/76 na omissão do contrato social. Contudo, isso não maculou sua existência, muito ao contrário as exigências do mercado deram concretude à Sociedade por Quotas.

Invocar as falhas legais da Lei de Quotas que, em virtude de opção legislativa, tratou de maneira tão simples da modalidade social mais utilizada em nosso país é, no mínimo, pobre em recursos e torná-la consectária das S. A é destruir sua natureza e derrogar sua norma originária.

Ao longo de trinta e dois artigos cuidou-se da constituição, administração e resolução da sociedade limitada, enquanto que para a $S$. A, apenas dois artigos foram suficientes para reportar-se à norma especial. 
Obrou mal o legislador no aspecto prático da sociedade limitada, embora sua intenção, crê-se, tenha sido complementar aquilo que restou em aberto no texto legal originário, mas que a profusão de sua utilização pôs fim às controvérsias, ou na pior das hipóteses, harmonizou as eventuais dissonâncias.

Obviamente que melhor seria a criação de novos recursos e alternativas viabilizadoras de proliferação deste ente societário, mesmo que com um novo diploma legal especial, como o fez no caso da Lei 6.404/76 que se manteve em vigor, após o advento do NCC. Contudo, a inserção do modelo redesenhado e a revogação da lei especial desta espécie empresarial parece vir na contramão da história.

Sem falar no fato de que com a superação da antiga característica que simplificava o desempenho das atividades empresariais da sociedade limitada, começaram a surgir empresas que estão optando em transformar sua modalidade societária em sociedade anônima de capital fechado.

Como antes já se vivenciava a proliferação da informalidade das empresas, ou seja, sociedades de fato e não de direito, vislumbra-se ampliação de tais empresas, quando na verdade dever-se-ia incentivar o surgimento de empresas formais, por via de conseqüência, geradoras de postos de trabalho, de arrecadação, distribuição de renda e de riquezas e propulsora de desenvolvimento econômico.

A $12^{a}$ Diretiva da União Européia demonstrou a importância de modalidade empresarial tão rica de alternativas tendentes ao desenvolvimento econômico, dando destaque ao programa de incentivo às pequenas e médias empresas ${ }^{12}$. Acresça-se a isso a criação de sociedade unipessoal que está a demonstrar a imprescindibilidade da sociedade limitada para os países europeus, o que, infelizmente, não é o caso do Brasil e não houve avanços, neste sentido, no Novo Código Civil.

\section{CONCLUSÃO}

O Novo Código Civil, apesar de tão aguardado, não só no quantitativo de anos, mas por conta das inúmeras expectativas por ele geradas, face ao universo de abrangência que veio açambarcar, frustrou àqueles a quem, verdadeiramente, deveria vir amparar.

O atrelamento da "vida social" da sociedade de responsabilidade limitada ao Novo Código Civil, em virtude do sepultamento do decreto 3.708/19, por seu

${ }^{12}$ Para buscar mais informações sobre os demais objetivos da $12^{\circ}$ Diretiva da União Européia ver Marshall (2002). 
turno, conduz a uma mudança de perspectiva que poderá gerar desconfortos iniciais até dificuldades operacionais intransponíveis sob o ponto de vista prático. Apesar da ausência de menção quanto à revogação da denominada Lei de Quotas, impinge-se o seu reconhecimento, uma vez que exsurgem novas regras para esta modalidade societária.

Atrevemo-nos a dizer que, a ausência de previsão específica que ampare a distinção realizada pelo constituinte e leve em conta o Estatuto da Microempresa e os avanços do SIMPLES, bem como a negligência à observância da estipulação de tratamento diferenciado às pequenas e microempresas como princípio da atividade econômica no NCC, quanto às Sociedades Limitadas, além de desarrazoadas, são frontalmente inconstitucionais.

Está-se diante de uma realidade que carece de reparos por diversos motivos, mas crê-se que o legislador ordinário fechou os olhos aos preceitos contidos na constituição, fato que poderá levar à transformação de sociedades limitadas em sociedades anônimas de capital fechado, ou, na pior das hipóteses, gerar a ampliação da informalidade. Contudo, a criatividade humana é surpreendente, sendo assim, pode ser que a interpretação teleológica da norma leve ao abrandamento das imposições técnicas supra apontadas, que ficará a cargo daqueles que litigam em juízo e dos nossos Tribunais.

\section{REFERENCIAS}

AMARAL, Hermano Villemor do. Das sociedades limitadas. Rio de janeiro: Jacintho Ribeiro dos Santos Editor, 1921.

. Das sociedades limitadas. 2. ed. Rio de Janeiro: F. Briguet \& Cia, 1938.

AVELLAR, Luciano. O papel da microempresa e da empresa de pequeno porte no contexto nacional. Florianópolis: IPEJ, 2001.

BORGES, João Eunápio. Curso de Direito Comercial terrestre. 5. ed. Rio de Janeiro: Forense, 1971.

CAMPINHO, Sérgio. O Direito de Empresa - à luz do Novo Código Civil. 2 ed. Rio de Janeiro: Renovar, 2003.

COELHO, Fabio Ulhoa. Curso de Direito Comercial. 5. ed. São Paulo: Saraiva, 2002.

FRANCO, Afonso Arinos de Melo. Curso de Direito Constitucional. Rio de Janeiro: Forense, 1960. v.1. 
GRAU, Eros Roberto. A ordem econômica na Constituição de 1988. 3. ed. São Paulo: Malheiros, 1997.

LIMA, Hermes. Introdução à ciência do Direito. Rio de Janeiro: Freitas Bastos, 1977.

MARSHALL, Carla Izolda Fiuza Costa. A sociedade por quotas e a unipessoalidade. Rio de Janeiro: Forense, 2002.

. Norma Jurídica Célula Mãe do Direito. Archè, Rio de Janeiro, n. 12, p. 141, jan./mar. 1995.

MARTINS, Fran. Curso de Direito Comercial. 22. ed. Rio de Janeiro: Forense, 1996.

- Das sociedades por quotas no direito estrangeiro e brasileiro. Rio de Janeiro: Forense, 1960.

OLIVEIRA, Celso Marcelo de. Direito empresarial à luz do Novo Código Civil. Campinas: LZN, 2003.

PEIXOTO, Carlos Fulgêncio da Cunha. A sociedade por quotas de responsabilidade limitada. Rio de Janeiro: Forense, 1956. v. 1.

SKIDMORE, Thomas. Brasil: de Getúlio a Castelo. Rio de Janeiro: Paz e Terra, 1976.

SOUTO, Azevedo. Lei das sociedades por quotas. 3. ed. Coimbra: Almedina, 1941.

SOUZA, Washington Peluso Albino de. Primeiras linhas de Direito Econômico. São Paulo: LTR, 1994.

VENTURA, Raúl. Comentários ao Código das Sociedades Comerciais - Sociedades por Quotas. 2. ed. Coimbra: Almedina, 1993. v. 1. 